\title{
Corruption Prevention in Legislative Drafting in Indonesia
}

\author{
BAYU DWI ANGGONO \\ Faculty of Law \\ Universitas Jember \\ Sumbersari, Jember, East Java 68121, Indonesia \\ INDONESIA \\ ROFI WAHANISA \\ Faculty of Law \\ Universitas Negeri Semarang \\ Gunung Pati, Semarang, Central Java 50229 \\ INDONESIA
}

\begin{abstract}
Corruption not only happens in the implementation of legislation or policy (administrative corruption) but also in the process of legislative drafting (state capture). Since the establishment of the Corruption Eradication Commission (KPK), many members of the House of Representatives (DPR), the Regional Legislative Council (DPRD), or government officials have been arrested and convicted of criminal acts due to legislative corruption. In legislative corruption, the actors involved consist of the interest parties and lawmakers. The interest parties attempt to obtain political, economic, and social benefits (supernormal profits) from the formulated legislation. To the same extent, the lawmakers expect the money or other personal benefits from the interest parties in return for the assistance given. Legislative corruption will lead to disorganized policy implementation, loss on the national economy, public distrust of the law-maker institutions, and longterm effect of distrust of law and democracy. Several prevention strategies of legislative corruption can be employed by improving four principles of legislative drafting: management, professionalism, justification, and public participation.
\end{abstract}

Key-Words: - Prevention, Corruption, Legislation, Legal Drafting, Politics of Law, Indonesia

Received: May 14, 2021. Revised: November 12, 2021. Accepted: December 17, 2021. Published: January 13, 2022.

\section{Introduction}

Corruption still becomes the biggest problem for many countries in achieving prosperity [1]. The government of Indonesia also acknowledge that corruption is a great enemy in realizing development as stated in the 2015-2019 National Medium-Term Development Plan (RPJMN). In the documents of 2015-2019 RPJMN, it is stated that corruption still is a serious challenge for development in Indonesia because it massively restricts the effectiveness of mobilization and allocation of development resources in reducing poverty and developing infrastructures. Moreover, corruption desperately hinders the achievement of sustainable development and prompts negative effects for the society. Therefore, corruption can be categorized as an extra-ordinary crime.

The International World classifies corruption into two types: state capture and administrative corruption. The World Bank defines state capture as the actions of individuals, groups, or firms in both the public or private sectors to influence the formulation of laws, regulations, decrees, and other government policies to their own advantage as a result of the illicit and non-transparent provision of private benefits to public officials [2]. In contrast, administrative corruption refers to the provision of such benefits to influence how these established rules are implemented.

On the one hand, state capture simply can be regarded as giving a bribe to state officials in drafting or making policies such as legislation or provisions in order to benefit a particular party. Administrative corruption, on the other hand, is giving a bribe to state officials in implementing/carrying out policies in order to give advantages for a particular party.

Both types of corruption can always be found in government. This follows George Jellinek's notion that government literally has two meanings: formal meaning and material meaning. In formal meaning, government holds governing power (verordnung 
gewalt) and decision-making power (entscheidungs gewalt). Conversely, government in material meaning has two elements: governing and implementing [3]. Based on this classification, it can be implied that government also involves governing power in terms of making regulations. This corresponds to the notion given by Van Wijk and W. Konbelt, stating that implementation (uiting) can refer to issuing provisions, other real actions, or the following regulations.

The terms 'state capture' and 'administrative corruption' are also relevant to be used in Indonesia. It follows the fact that various cases of corruption handled by law enforcement officers included these types of corruption. Based on the data from the Corruption Eradication Commision (KPK), from its establishment to December 31, 2018, the agency has been handling corruption cases that consisted of: initial investigation on 164 cases, investigation on 199 cases, closing address on 151 cases, permanent legal binding (inkracht) on 106 cases, and execution on 113 cases [4]. These cases involved 229 members of the House of Representatives (DPR) and the Regional Legislative Council (DPRD), 20 governors, and 91 mayors and regents.

The cases handled by the KPK involve procurement of goods and services, licensing, bribery, levy, misuse of budget, money laundering, and upholding the verdict from the KPK. Regarding the bribery case, there are at least two categories of bribery: bribes given to state officials in implementing policies and the ones given to state officials in drafting policies (legislation).

An example of bribery in the implementation of policies was the case of Luthfi Hasan Ishaaq, which happened when he still served as a member of the House of Representatives. In a legally binding court judgement, the Chairman of the Supreme Court (MA) sentenced him to 18 years' imprisonment as he had transactional relations and misused his position to get money from a beef businessman. The bribe was aimed to increase the import quota of beef for the businessman [5 - 7].

In addition, bribes given to the state officials in drafting policies, especially legislation, can also be found in central and regional levels. One example of this bribery was the case regarding the formulation of Law of Bank Indonesia (BI). In this case, a large amount of money (IDR 31.5 billion) taken from the Indonesian Banking Development Institute was distributed to some members of the House of Representatives to maintain BI's interest in discussing an amendment of Law of BI and addressing issues on the Bank Indonesia Liquidity Support (BLBI). Some members of the House of
Representatives such as FPG Hamka Yandhu, Anthony Zeidra Abidin, and the others were convicted of bribery in this case [8].

Corruption in legislative drafting also happens on a regional level. An obvious example was the case of 41 members of the Malang Legislative Council who were suspected of receiving grants to ease the discussion on the draft of bylaw regarding the 2015 revised regional budget (APBD-P) [9]. A similar case was also found in Jambi where 12 members of the Jambi Legislative Council were convicted of receiving a varied number of bribes. The bribes were aimed to make the speaker and the members of the Council approve the draft of bylaw regarding the 2017 and 2018 regional budget [10].

The loss caused by state capture was massive. It is not only because of the loss on the national budget, but it also leads to high cost of economy, loss on the national economy, obstruction in reducing poverty, public distrust of the law-maker institutions, and long-term effect of distrust of law and democracy [11 - 13]. According to this description, in order to prevent the negative effects of state capture, especially in legislative drafting, prevention strategies need to be developed. In addition to prosecution, the strategies can be geared towards means of encouraging prevention aspects. Therefore, this study attempts to discuss: 1) how the problems in legislative drafting in Indonesia are, especially in terms of legislative corruption, and 2) how strategies are employed to prevent corruption in legislative drafting in Indonesia.

\section{Requirements of Good Legislative Drafting}

Establishment of a product of legislation involves three interrelated corridors: administration corridor, academic corridor, and politics corridor [14]. Administration corridor refers to compliance with provisions regarding the process of legislative drafting. Academic corridor means that legislative draft must be academically accountable. Politics corridor is not only related to a political institution, but legislative draft interchangeably must be able to receive and correspond to public aspirations.

Otto et al. [15] summarize five theories describing configuration of factors and actors in legislative drafting. They consist of synoptic-phases theory, agenda-building theory, elite ideology theory, bureau-politics theory or organizational politics theory, and four rationalities theory. In the synoptic-phases theory, the process of legislative drafting is illustrated as a well-organized process 
from its decision making which gives direction to the society as a whole. According to this theory, policies are developed under the supervision from politically accountable institutions which have particular roles, where political actors refer to those who are accountable for determining the contents of the legislation. On the contrary, in the agendabuilding theory, legislative drafting is described as a disorganized process elicited from a social process in which ideas contradict different interests. In this case, the parties having interests seek to gain access to political agenda in order to offer a concept of controlling legislation.

In the elite ideology theory, the process of legislative drafting is motivated by the ambition of political elite inspired by jargon, values, or new principle (informing principle) from more developed or modern countries/society to be applied to their society which are not involved in the formulation of legislation. Unfortunately, the jargon, values, ideology, or new principle (informing principle) are generally not relevant to the social reality so that eventually they just lead to resistance and even stagnation. In the bureau-politics theory or organizational politics theory, the process of legislative drafting is not established based on rational formation or a process encouraged by the society, but it is just a competition of authority between state organizations. In discussing legislative draft, the variety of tasks and control range of each institution prompts sectoral ego among the institutions when the discussed issue is within their range.

In the four rationalities theory, laws and regulations have four dimensions, and each of which has their own rationality. These four dimensions consist of: political dimension, legal dimension, economic dimension, and scientific dimension. They sometimes work jointly or separately, or even they reduce one another. In developing countries, political dimension generally tends to be dominant than the others because political institutions have significant impacts in people's lives.

The state's authority in legislative drafting basically needs to be accompanied by various requirements of good legislative drafting. This is based on several considerations. First, as legal products, laws and regulations are heavily influenced by politics, especially in the drafting process. Mahfud [16] argues that legislative drafting, in fact, tends to make political decisions rather than carry out legal works. The influence of politics in legislative drafting will not cause problems when the political configuration is democratic as the character of legal products presented are likely to be responsive/populist. However, it will bring problems if the configuration is authoritarian because the legal products tend to be conservative/orthodox/elitist.

Second, the laws that contain legislation is a legal governing instrument in a country. In this position, laws have the power to force the society. Regarding the existence of laws in the society, Kusumaatmadja [17] states that the main objective of laws is to guarantee order, justice, and certainty. Therefore, laws work as a system which stimulates and governs people's lives.

Due to such characteristic, laws are regarded as a governing tool which can make a social change. In this position, laws can eventually arise from two contrary sides. Laws can be a legal tool for an authoritarian regime to govern the society arbitrarily and unjustly. Conversely, laws can create justice for the society and control the authority from being arbitrary. As a result, several requirements are needed to prevent legislation which governs the society arbitrarily and unjustly.

Third, according to Niemivuo [18], it is important to give attention to legislative drafting because the contents of legislation influence not only the decision makers but also all of the most important functions of society. Niemivuo [18] further explains:

The most fundamental structures of society and the most important norms of behaviour are laid down by legislation. In its entirety, legislation reflects society - its decision-makers and civil servants. Statutory law has an effect - at least indirect - on all the most significant functions of society. Since an important part of social development is planned through legislative drafting, special attention should be paid to the quality and development of legislative drafting.

Fourth, it is needed to ensure that the legislation made can be understood correctly and acceptable to the majority of public as the objects of the legislation. It is because the objects vary from those studying laws to experts [19]. There are good people who will try to understand legislation and those with bad intentions in understanding legislation. Hence, it is needed simple legislative drafting with proper and suitable language composition so that everyone can understand the terminologies correctly.

Good legislative drafting should be based on empirical studies by involving active public participation. By implementing those elements, legislative drafting not only represents decision makers' top-down interests but also reflects public 
aspirations in influencing the process of policy making [20].

In addition to those four considerations, good legislative drafting, especially in Indonesia, is important in order to achieve the objective as a welfare state, which is a constitutional mandate and needs to be formulated and implemented in state administration practice. Consequently, the state's responsibility in realizing government is to achieve the national objectives [21].

In addition, in a welfare state intervention from the state/government in various life aspects of the society is unavoidable. In this case, the intervention must be formulated in the form of laws or legislation that force the society in both national and regional levels. Thus, realizing state administration cannot be separated from policies formulated in legislation and implemented in actions. There are many reasons underlying the importance of developing the quality of legislative products in both national and regional levels. It is because the development dynamics of Indonesian society is quite rapid in all sectors including social, political, legal, living environment, education, and defence and security sectors.

Regarding the requirements of good legislative drafting, Attamimi [22] divides legal principles in legislative drafting into two: (1) formal legal principles and (2) material legal principles. Formal legal principles are related to 'how' a regulation is implemented, while material legal principles refer to 'what' a regulation contains. According to Attamimi [22], formal legal principles consist of: 1) the principle of clear objective; 2) the principle of necessity of regulation; 3 ) the principle of right organ/institution; 4) the principle of proper content materials; and 5) the principle of applicability. On the other side, material principles involve: 1) the principle of accordance with the ideals of laws and fundamental norms of the state; 2) the principle of accordance with the national laws; 3) the principle of accordance with the national principles based on laws; and 4) the principle of accordance with government principles based on the constitution.

Stijn Debaene et al. [23] state that there are criteria (principles) that determine the quality of legislation. The criteria are classified into formal and material criteria. On the one hand, formal criteria are about the contents. On the other hand, formal criteria are related to structure and design. Material and formal criteria have different procedures in the drafting process. Material criteria deal with preparation tasks in the drafting process such as definitions, problems, problem analyses, generating alternative solutions, etc. On the contrary, formal criteria refers to phases in the drafting process where the norm contents turn to a well-organized legislation draft. Several examples of material criteria are clear objective, applicable enforcement, effectiveness and efficiency, consistency and compatibility with the principles of legal certainty, and equal rights. Examples of formal criteria are normative character, comprehensibility, publicity, and regulations in a proper level.

Van der Vlies and Doludjawa [24] distinguishes principles in drafting good national regulations (beginselen van behoorlijke regelgeving) into formal and material principles. Formal principles include: 1) principle of clear objective (beginsel van duidelijke doelstelling); 2) principle of the right organ/institution (beginsel van het juiste organ); 3) the principle of necessity of regulation (het noodzakelijkheidsbeginsel); 4) the principle of enforceability (het beginsel van uitvoerbaarheid); and 5) consensus principle (het beginsel van consensus). Material principles comprise of: 1) the principle of clear terminology and system (het beginsel van duidelijke terminology en duidelijke systematiek); 2) the principle of recognisability (het beginsel van de kenbaarheid); 3) the principle of legal equality (het rechtsgelijkheids-beginsel); 4) the principle of legal certainty (het rechtszekerheidsbeginsel); and 5) the principle of the individual administration of justice (het beginsel van der individuele rechtsbedeling).

\section{Corruption in Legislative Drafting in Indonesia}

Based on Law No. 31/1999 juncto Law No. 20/2001 on Corruption Eradication (Law of Tipikor), there are 30 types of corruption. All of those types basically can be further classified into seven major types: i) state financial loss; ii) bribery; iii) embezzlement; iv) extortion; v) fraud; vi) conflict of interest in a procurement; and vii) gratification.

Based on the recapitulation of corruption in Indonesia, the KPK divides corruption into five categories: corruption based on institution, based on types of case, based on profession/position, based on permanent legal binding (inkracht) case, and based on region. The recapitulation aims to provide a brief report on the KPK's performance in enforcement practice. The recapitulation is also reported and renewed periodically.

Table 1. Corruption based on institution

\begin{tabular}{|l|l|l|l|l|l|l|}
\hline \multirow{2}{*}{ No } & \multirow{2}{*}{ Institution } & \multicolumn{3}{|l|}{ Year } & \multicolumn{5}{|c|}{} \\
\cline { 3 - 7 } & & 2015 & 2016 & 2017 & 2018 & 2019 \\
\hline
\end{tabular}




\begin{tabular}{|l|l|l|l|l|l|l|}
\hline 1 & $\begin{array}{l}\text { The House of } \\
\text { Representatives } \\
\text { (DPR) and Regional } \\
\text { Legislative Council } \\
\text { (DPRD) }\end{array}$ & 3 & 15 & 9 & 4 & 6 \\
\hline 2 & Ministry & 21 & 39 & 31 & 47 & 42 \\
\hline 3. & $\begin{array}{l}\text { State-Owned } \\
\text { /Region-Owned } \\
\text { Enterprises } \\
\text { (BUMN/BUMD) }\end{array}$ & 5 & 11 & 13 & 5 & 17 \\
\hline 4 & Commission & 0 & 0 & 0 & 0 & 0 \\
\hline 5 & $\begin{array}{l}\text { Provincial } \\
\text { Government }\end{array}$ & 18 & 13 & 15 & 29 & 4 \\
\hline 6 & $\begin{array}{l}\text { District/City } \\
\text { Government }\end{array}$ & 10 & 21 & 53 & 114 & 51 \\
\hline Total & 57 & 99 & 121 & 199 & 120 \\
\hline
\end{tabular}

Source: [25]

Table 2. Corruption based on position

\begin{tabular}{|c|c|c|c|c|c|c|}
\hline \multirow{2}{*}{ No } & \multirow{2}{*}{ Position } & \multicolumn{5}{|l|}{ Year } \\
\hline & & 2019 & 2018 & 2017 & 2016 & 2015 \\
\hline 1. & $\begin{array}{l}\text { Members of the } \\
\text { House of } \\
\text { Representatives } \\
\text { (DPR) and Regional } \\
\text { Legislative Council } \\
\text { (DPRD) }\end{array}$ & 10 & 103 & 20 & 23 & 19 \\
\hline 2. & $\begin{array}{l}\text { Chief of } \\
\text { Institution/Minister }\end{array}$ & 2 & 1 & 0 & 2 & 3 \\
\hline 3. & Ambassador & 0 & 0 & 0 & 0 & 0 \\
\hline 4. & Commissioner & 0 & 0 & 0 & 0 & 0 \\
\hline 5. & Governor & 1 & 2 & 1 & 1 & 3 \\
\hline 6. & $\begin{array}{l}\text { Mayor/Regent and } \\
\text { Vice Mayor/Regent }\end{array}$ & 14 & 30 & 13 & 9 & 4 \\
\hline 7. & $\begin{array}{l}\text { Echelon I/ II/ III } \\
\text { Official }\end{array}$ & 14 & 24 & 43 & 10 & 7 \\
\hline 8. & Judge & 0 & 5 & 3 & 1 & 3 \\
\hline 9. & Prosecutor & 3 & 0 & 1 & 3 & 0 \\
\hline 10. & Police & 0 & 0 & 0 & 0 & 0 \\
\hline 11. & Lawyer & 1 & 4 & 0 & 1 & 2 \\
\hline 12. & Private Official & 49 & 56 & 28 & 28 & 18 \\
\hline 13. & Others & 32 & 31 & 13 & 21 & 3 \\
\hline 14. & Corporation & 1 & 4 & 1 & 0 & 0 \\
\hline Tota & & 127 & 260 & 123 & 99 & 62 \\
\hline
\end{tabular}

Source: [25]

Table 3. Corruption Based on Types of Case

\begin{tabular}{|c|c|c|c|c|c|c|}
\hline \multirow{2}{*}{ No } & \multirow{2}{*}{ Case Type } & \multicolumn{5}{|l|}{ Year } \\
\hline & & 2015 & 2016 & 2017 & 2018 & 2019 \\
\hline 1. & $\begin{array}{l}\text { Procurement of } \\
\text { Goods/Services }\end{array}$ & 14 & 12 & 15 & 17 & 17 \\
\hline 2. & Licensing & 1 & 1 & 2 & 1 & 0 \\
\hline 3. & Bribery & 38 & 79 & 93 & 168 & 97 \\
\hline 4. & Levy & 1 & 1 & 0 & 4 & 1 \\
\hline 5. & Misuse of Budget & 2 & 1 & 1 & 0 & 2 \\
\hline 6. & Money Laundering & 1 & 3 & 8 & 6 & 3 \\
\hline 7. & $\begin{array}{l}\text { Upholding the } \\
\text { Verdict from KPK }\end{array}$ & 0 & 0 & 2 & 3 & 0 \\
\hline Tot & & 57 & 99 & 121 & 199 & 120 \\
\hline
\end{tabular}

Source: [25]

With regard to the statistical data from the KPK above, it can be seen that corruption in legislative drafting moves from the executive to parliament. It cannot be separated from normative reality about the shift of power in law making from the President to the House of Representatives. Corruption and power can be illustrated as two sides of the same coin. Corruption always follows power, and conversely power becomes a starting point for corruption practice [26]. Law No. 12/2012 on legislative drafting stipulates that legislative drafting includes several stages: planning, drafting, discussion, ratification or establishment, and passage. Each stage has a vulnerability level to the possibility of corruption practice in legislative drafting.

Corruption within the scope of legislation often involves law and bylaw transactions. Mahfud [16] states governing means upholding constitution, and upholding constitution means complying with laws. In order to achieve the national objectives and ideals, it is required to comply with laws, and at least there are two essential things in complying with laws: "making" laws which are abstract (in abstracto) and "implementing" or enforcing legislation into the real practice (in concreto). Mahfud [16] further argues there are four mistakes in law making: First, there are political trade-offs between politicians or political organizations in the law-maker organizations. Despite taking dislikes, the trade-offs can be understandable. Second, there is a lack of knowledge among the law or bylaw makers. It also becomes understandable that the members of the parliament are chosen because of great political support, not because of their capability and professionalism. Third, there is a minor technical problem. For instance, an article X is supposed to be further regulated in the government regulation, but it is written article Y. Such problem can be understood. However, when it has been already established, the correction requires not only renvoi but also legislative review or judicial review. Fourth, there are transactions of law or bylaw contents in order to obtain illegal benefits from particular articles in the laws or bylaws. It is obvious that the suspects have been listed by the KPK and/or in the court verdict. Most of them are sentenced to prison, including those in both central and regional levels.

One of the examples of corruption involving officials in legislative drafting is the case of Murman Effendi, the regent of Seluna regency Bengkulu, and some members of Seluma Regional Legislative Council in 2010 [27]. The case began in the end of 2010 when Murman Effendi had a meeting with some members of the Council to discuss a bylaw draft (Raperda) on budget increase for building road and bridge infrastructure with hotmix construction through the implementation of multi-year work for 5 fiscal-year period. In that 
meeting, the regent promised an amount of money if the draft was approved by the Council.

After the draft got the approval from the Council, on December 8, 2010 the regent established it as the Bylaw No. 12/2010. The regent then deliberately set PT. Puguk Sakti Permai (PT. PSP) as the winner of the multi-year project tender that was ratified in a work agreement on March 15, 2011 on the development and urban planning of Tais as the capital of Saluma with hotmix road construction with contract value of IDR 338 billion.

On March 25, 2011 the regent held a meeting with the members of the Council, Erwin (the Chairman of Public Works Office), Mirin (the Chairman of Legal Affairs), and Ali (the Director of PT. PSP) to discuss the proposal of revising the Bylaw No. 12/2010. The regent said that the bylaw was revised due to a change. Initially, the roads of Datuk - Simpang Enam were supposed to be widened and divided into two ways by using national roads. However, because of unfavorable natural conditions (soil condition and settlement), the roads needed to be moved to the southern direction from Talang Dantuk village by building new roads leading to budget increase.

In that meeting, the regent fulfilled his promise to give the money to 27 members of the Council as they approved the revision of the Bylaw No. $12 / 2010$. The money was given in the form of cheque for IDR 50 million and additional fee of IDR 1-1.5 million to every member of the Council for the plenary meeting discussing the change.

Then, on March 30, 2011 within one day all fractions of the Council approved the revision, from the Bylaw No. 12/2010 to the Bylaw No. 2/2011, increasing the budget from IDR 360 billion to IDR 381 billion. On April 4, 2010 the regent ratified the Bylaw No. 2/2011 on budget increase for building road and bridge infrastructure with hotmix construction through the implementation of multiyear work for 5 fiscal-year period. On April 7 and 12, 2011 the regent realized his promise to give the amount of money of IDR 50 million to the members of the Council through Ali.

Because of the conduct, the Corruption Court (Tipikor), through the Judgement No. 75/Pid.B/TPK/2011/PN.JKT.PST February 21, 2012 sentenced the non-active regent, Murman Effendi, to 2 years' imprisonment and IDR 100 million fine of 3 months' imprisonment subsider. The judgement was supported by the Jakarta High Court through the Judgement No. 20/Pid.B/TPK/2012/PT.DKI May 9, 2012. In the end, the judgement became a permanent legal binding (inkracht) when the Supreme Court rejected Murman Effendi's appeal through the Judgement No. 1391K/Pid.Sus/2012 August, 92012.

The speaker/deputy speakers and the members of the Council were also given sentences. In this case, the speaker of the Council, Zaryana, was sentenced to 4 years' imprisonment and IDR 200 million fine of 2 months subsider [28]. Besides, the deputy speakers of the Council, Jonaidi Syahri \& Muchlis Tohir, were sentenced to 4 years 6 months' imprisonment and IDR 200 million fines of 3 months' subsider by the Panel of Judges of the Jakarta Corruption Court on February 13, 2014 [29]. Pirin Wibisono was one of the members given the sentence. He was sentenced to 4 years' imprisonment and a fine of IDR 300 millions of 3 months' subsider on December 19, 2013 [30].

Corruption practice involving law makers and a private party also happened in DKI Jakarta in 2016. This case involved the chairman of Commission D of the DKI Jakarta Regional Legislative Council, M. Sanusi, who was caught in the act on March 31, 2016 after receiving a bribe related to discussion on bylaw drafts (Raperda) on Jakarta's 2015-2035 coastal area and small-offshore island zoning and spatial planning of Jakarta north-coast strategic area. A bribe of IDR 2 billion was given to Sanusi by the director of PT. Agung Podomoro Land, Ariesman Widjaja [31].

This bribery case began when PT. Kapuk Naga Indah, which was the subsidiary of Agung Sedayu Group corporation, PT. Muara Wisesa Samudra, PT. Agung Dinamika Perkasa, and PT. Jaladri Kartika Pakci who's the majority of the shares were owned by PT. Agung Podomoro Land Tbk and PT. Jakarta Propertindo were selected as the holders of principal agreement on reclamation of Jakarta north coast. These corporations required a bylaw on spatial planning of Jakarta north-coast strategic area (RTRKSP Jakarta) as a legal basis to put up buildings on the reclamation lands [32].

The bribe given to M. Sanusi was intended to ease the discussion on the bylaw draft of RTRKSP Jakarta. In addition, M. Sanusi was expected to eliminate the article regulating $15 \%$ contribution from taxable value of property (NJOP) of the lands sold. In order to grant the request, on March 7, 2016 M. Sanusi called Heru Wiyanto, the chairman of legislative affairs of DKI Jakarta Regional Legislative Council Secretariat, to submit the bylaw draft of RTRKSP Jakarta February 22, 2016. At that time, M. Sanusi gave Heru handwriting regarding the changes on the Article 110 section (5) letter $\mathrm{c}$ on that contribution.

Because of his conduct, the Jakarta Corruption Court had proven that Sanusi received a bribe of 
IDR 2 billion from the boss of Agung Podomoro Land, Ariesman Widjaja. The money was related to the discussion of the bylaw draft of RTRKSP Jakarta in the Council's Legislation Agency (Balegda) of the Jakarta Regional Legislative Council. Sanusi was sentenced 7 years' imprisonment in the first level court. The prosecutor then appealed, and the sentence was added into 10 years' imprisonment. This judgement was supported by a cassation decision. In the judicial review (PK), the sentence was reduced into 7 years' imprisonment [33]. At the same time, the bribe provider, Ariesman Widjaja, was sentenced to 3 years' imprisonment and a fine of IDR 200 millions of 3 months' subsider. The judge panel of the Jakarta District Corruption Court believed that Ariesman was proved to have given a bribe of IDR 2 billion to M. Sanusi regarding the discussion on the bylaw draft of spatial planning of Jakarta northcoast strategic area [34].

\section{Corruption Prevention Strategies in Legislative Drafting in Indonesia}

Regarding law enforcement in corruption practice, the Indonesian government have made various means to eradicate corruption and save the state finance. Different products of legislation, institutions, and special teams have been established to eradicate corruption entirely. Corruption is a serious threat which not only damages many sectors of the national economy, but it also affects the international economic system and weakens democratic and justice values in all countries [35].

Muladi [36] states that law enforcement in corruption prevention depends on formulation, application, and execution stages. The application stage of law enforcement is a sophisticated process because it involves many parties (e.g., police, attorney, court, correctional institutions, and legal advisors) who have different perspectives in achieving the objective. These stages are considered satisfactory in terms of their formulation, accountability system, mechanism, and implementation rules. Law enforcement involves at least 2 meanings [16]. First, it refers to the settlement by the court and law-enforcement officers on a sued conflict or violation. Second, it refers to the implementation of legislation in everyday activities by the authority or government bureaucracy officers. In fact, law enforcement both in settling a conflict in the court and in implementing legislation in daily life is still infiltrated by corruption, collusion, bribery, extortion, etc.

From the discussion on corruption and prevention strategy in the framework of legislative drafting in Indonesia, the corruption in the House of Representatives not only occurs in realizing budgeting function but also in legislative function [37]. Corruption, according to the World Bank, is categorized into two types [38]: administrative corruption and state capture. The former involves deliberate actions in hindering the implementation of policy, decision, or provisions of legislation in order to obtain individual advantages. The latter refers to individual, collective, or corporal actions in both public or private sectors in influencing legislative, decision, or policy drafting in order to benefit the involved parties. In other words, administrative corruption occurs in the context of the implementation of policy, decision, or provisions of legislation, while state capture occurs in legislative, decision, or provision drafting.

Shift of corruptive behavior in legislative drafting from the executives to parliament cannot be separated from the normative reality about the shift of power in law making from the President to the House of Representatives. As corruption and power work like two sides of the same coin, corruption always follows power, and conversely power becomes a starting point for corruption practice [39].

Legislative drafting ideally consists of three points principles of good legislative drafting, 2) good legal politics (national legislation), and 3) proper legislative assessment [40]. Law No. 12/2011 stipulates that legislative drafting involves several stages: planning, formulation, discussion, ratification or establishment, and passage [26]. Each stage has a vulnerability level to the possibility of corruption practice in legislative drafting.

With regard to those stages, the model proposed by Klitgaard et al. [39] can be adopted to minimize the possibility of doing corruption in legislative drafting. The model embraces four principles: management, professionalism, justification, and public participation. Management is a very important aspect. The problem of integration between the institutions responsible for ensuring that legislative drafting follows the guidelines as stated in Law No. 12/2011 must be solved immediately. The notion of establishing an institution in legislative drafting such as a national regulatory center or national regulatory organization needs to be realized.

Professionalism is realized through technical skills in legislative drafting. Drafting also aims to 
explain and express the lawmakers' intention. Therefore, professionalism is extremely needed. In addition, independence in drafting and harmonizing legislation must be guaranteed through laws in order to resist intervention from a particular interest.

Justification means that various interests in legislative drafting can be minimized by strengthening the position of academic scripts including draft of laws or bylaws. The academic scripts must be restored from their function as just a formality in fulfilling the requirements of law and bylaw drafting to a justification of the importance of legislation as well as guidelines on content drafting in legislation. If there is a proposed content which is irrelevant to the philosophical, juridical, and sociological principles in the academic scripts, the proposal must be rejected.

The next aspect is public participation. Law No. $12 / 2011$ states that transparency is one of the principles which must be followed by every lawmaker. The law stipulates that individuals or groups who have an interest in the draft substance are allowed to give input verbally or in writing form through public hearing, work visit, socialization, seminar/workshop/discussion. However, Law No. 12/2011 still does not specifically regulate on which stage the participation takes place and how the mechanism works. Therefore, formal guidelines need to be developed regarding how lawmakers guarantee the participation given can influence the contents of legislative draft.

Participation or public involvement in the process of making public policy, public policy program, and public decision as well as its reason (in the context of legislative drafting) is one of the characteristics of a democratic state [41]. Participation can be interpreted as involvement or taking part in an activity, starting from the planning to evaluation. Public participation in the process of legislative drafting can be categorized as political participation. Huntington and Nelson [42] define political participation as private citizens' activities which attempts to influence decision making by the government.

Participation also needs to be encouraged by transparency in the process of legislative drafting [43]. According to Law No. 12/2011, in order to disseminate information regarding the activities carried out by the House of Representatives and government from formulating national legislative programs, drafting laws, discussing drafts, and passage, lawmakers must provide information and/or receive input from the public and stakeholders as a part of public participation [44]. The lawmakers can use advanced technologies to provide information regarding legislative drafting transparently and receive public aspirations through an online system. For instance, a draft can be accessed in real time, and everyone is allowed to give input. The discussion can also be carried out transparently by broadcasting it through the government's and/or the House of Representatives' platforms.

\section{Conclusion}

The international world classifies corruption into two types: state capture and administrative corruption. State capture refers to giving a bribe to state officials in drafting or making policies such as legislation or provisions in order to benefit a particular party. Administrative corruption, on the other hand, can be regarded as giving a bribe to state officials in implementing/carrying out policies in order to give advantages for a particular party. The terms 'state capture' and 'administrative corruption' are also relevant to be used in Indonesia because one of the cases handled by the KPK is bribery giving a bribe to state officials in implementing and formulating policy in the form of legislation.

Corruption within the scope of legislation often involves law and bylaw transactions. The transactions are aimed to obtain illegal advantages from infiltrating particular articles into laws or bylaws. An example of the transaction was found in Seluma, Bengkulu in 2010 which involved the regent of Seluma and some members of the Seluma Regional Legislative Council in bylaw drafting, in which bribes were given by a private party having interest in the content of the draft. A similar case also happened in DKI Jakarta in 2016 which involved some members of the DKI Jakarta Regional Legislative Council and a private party who gave bribes as the contents of the bylaw draft were considered disadvantageous for its business interest.

A model developed by Klitgard can be adopted in Indonesia in preventing legislative corruption. The model consists of four principles: management, professionalism, justification, and public participation. The principle of management can be realized by establishing an institution in legislative drafting such as a national regulatory center or national regulatory organization. In terms of professionalism aspect, in addition to improving technical skills in legislative drafting, lawmakers' independence in formulating and harmonizing legislation must be guaranteed through laws in order to resist intervention from a particular interest. 
Justification can be carried out by restoring the function of academic scripts from just a formality in fulfilling the requirements of law and bylaw drafting to a justification of the importance of legislation as well as guidelines on content drafting in legislation. Finally, in terms of public participation formal guidelines regarding how lawmakers guarantee public participation needs to be developed. The guidelines also guarantee how the participation given can influence the contents of legislation.

\section{References:}

[1] Bracking S., Corruption and development, Hampshire: Palgrave Macmillan, 2007.

[2] Gray C. W., Hellman J. S., Ryterman R., Anticorruption in transition 2: corruption in enterprise-state interactions in Europe and Central Asia, 1999-2002, World Bank Publications, 2004.

[3] Sjarif F. A., Kasus Marbury V. Madison dan Judicial Review di Amerika Serikat, In Aradhana Sang Guru Perundang-undangan, Jakarta: Badan Penerbit Fakultas Hukum Universitas Indonesia.

[4] Anti-Corruption Clearing House (ACCH), Rekapitulasi Tindak Pidana Korupsi, 2018, retreived from https://acch.kpk.go.id/id/statistik/tindak-pidanakorupsi.

[5] Wedhaswary I. D., Hak Politik Luthfi Hasan Ishaaq Dicabut, Hukumannya Diperberat Jadi 18 Tahun, Kompas, 16 September 2014. Available: https://nasional.kompas.com/read/2014/09/16/06315 561/hak.politik.luthfi.hasan.ishaaq.dicabut.hukuman nya.diperberat.jadi.18.tahun.

[6] Pramono C. A., Manurung A. H., Heriyati P., Kosasih W., Analysis of the influence of entrepreneurship capability, agility, business transformation, opportunity on start-up behavior in ecommerce companies in Indonesia during the covid 19 pandemic. WSEAS Transactions on Business and Economics, vol. 18, pp. 1103-1112, 2021.

[7] Sadma O., The Role of Environmental-Based "Green Startup" in Reducing Waste Problem and its Implication to Environmental Resilience, Research Horizon, vol. 1, no. 3, pp. 106-114, 2021.

[8] Anggono B. D., Perkembangan pembentukan undang-undang di Indonesia, Jakarta: Konstitusi Press, 2014.

[9] BBC News Indonesia, DPRD Kota Malang: Ketika 41 dari 45 anggota terjerat korupsi dan ditahan KPK. BBC News Indonesia, 4 September 2018, retrieved from https://www.bbc.com/indonesia/indonesia45405591.

[10] Rachman D. A., Kembangkan Kasus Zumi Zola, KPK Tetapkan 3 Pimpinan dan 9 Anggota DPRD Jambi sebagai Tersangka, Kompas, 28 December 2018, retrieved from https://nasional.kompas.com/read/2018/12/28/16470 481/kembangkan-kasus-zumi-zola-kpk-tetapkan-3pimpinan-dan-9-anggota-dprd-jambi.

[11] Chernova V. Y., Degtereva E. A., Forecast of Development of the Dual-Use Industrial Products Market, WSEAS Transactions on Business and Economics, vol. 17, pp. 987-992, 2020.

[12] Eldar A. G, Problems of Financial and Investment Support Modelling of the Regional Social and Economic Development, WSEAS Transactions on Business and Economics, vol. 17, pp. 741-752, 2020.

[13] Bukhori A., The Role of Youth in Managing Educational Startup: Case Study of PrivatQ Startup, Research Horizon, vol. 1, no. 2, pp. 62-70, 2021.

[14] Mahendra Y. I., Bahan Penjelasan Mensesneg pada Rapat Kerja dengan Komisi II DPR RI Tanggal 25 Januari 2006, presented on work meeting between the Minister of State Secretariat and Commission II of the House of Representatives, Jakarta, 2006.

[15] Otto J. M., Stoter W. S. R., Arnscheidt J., Rooij B. V. (2008). Using legislative theory to improve law and development assistance, in Arnscheidt J., van Rooij B., Otto, J. M. (eds.), Lawmaking for Development. Explorations into the Theory and Practice of International Legislative Projects, pp. 53-74, Leiden: Leiden University Press.

[16] Mahfud M. D., Politik hukum di Indonesia. Jakarta: LP3ES, 1998

[17] Kusumaatmadja M., (2002). Konsep-konsep hukum dalam pembangunan: kumpulan karya tulis, Salman R. O., Damian S. E (eds)., Bandung: Pusat Studi Wawasan Nusantara, Hukum, dan Pembangunan in collaboration with Alumni.

[18] Niemivuo M. (2010). Legislative Drafting Process. Main Issues and Some Examples, Report CDLUDT(2010)018, Unidem Campus Trieste Seminar, Venice Commision, June 14-17, 2010. Retrieved from

https://www.venice.coe.int/webforms/documents/de fault.aspx?pdffile=CDL-UDT(2010)018-e.

[19] Nampoothiry N. K., The role of Parliamentary Counsel in legislative drafting, Commonwealth Law Bulletin, vol. 36, no. 1, pp. 57-65, 2010.

[20] Riskiyono J., Partisipasi masyarakat dalam pembentukan perundang-undangan untuk mewujudkan kesejahteraan, Aspirasi: Jurnal Masalah-masalah Sosial, vol. 6, no. 2, pp. 159-176, 2015.

[21] Thaib D., Peran Ideal DPD Dalam Sistem Ketatanegaraan Indonesia. Paper presented at a public discussion "Peran Sinergitas DPD RI dengan Pemerintahan Daerah dalam Pelaksanaan Otonomi Daerah", Pusat Studi Hukum Konstitusi FH UII bekerjasama dengan DPD RI, Yogyakarta, 2008.

[22] Attamimi A. H. S. (ed.), Peranan keputusan presiden republik Indonesia dalam penyelenggaraan pemerintahan negara: suatu studi analisis mengenai keputusan presiden yang 
berfungsi pengaturan dalam kurun waktu PELITA IPELITA IV, Jakarta: Universitas Indonesia, 1990.

[23] Debaene S., Van Kuyck R., Van Buggenhout B., Legislative technique as basis of a legislative drafting system, Information \& Communications Technology Law, vol. 9, no. 2, pp. 149-159, 2000.

[24] van der Vlies I. C., Doludjawa L., Buku pegangan perancang peraturan perundang-undangan, Jakarta: Direktorat Jenderal Peraturan Perundang-Undangan, Departemen Hukum dan Hak Asasi Manusia Republik Indonesia, 2005.

[25] Komisi Pemberantasan Korupsi (KPK), Laporan Tahunan 2018. Jakarta: Komisi Pemberantasan Korupsi, 2018, retrieved from https://www.kpk.go.id/id/publikasi/laporantahunan/934-laporan-tahunan-kpk-2018.

[26] Sanusi H. A., Relasi antara korupsi dan kekuasaan. Jurnal Konstitusi, vol. 6, no. 2, pp. 83-104, 2009.

[27] Anti-Corruption Clearing House (ACCH), Murman Effendi, 2019, retrieved from, https://acch.kpk.go.id/id/jejak-kasus/148-murmaneffendi.

[28] Detik.com, Terbukti Terima Suap, Ketua dan Anggota DPRD Seluma Divonis 4 Tahun, 19 December 2013, retrieved from https://news.detik.com/berita/d-2446929/terbuktiterima-suap-ketua-dan-anggota-dprd-selumadivonis-4-tahun.

[29] Hukumonline.com, Eks Wakil Ketua DPRD Seluma Divonis 4,5 Tahun Penjara. 14 February 2014, retrieved frim https://www.hukumonline.com/berita/baca/lt52fe22 1dda818/eks-wakil-ketua-dprd-seluma-divonis-4-5tahun-penjara/.

[30] Azhar R., KPK Sudah Penjarakan 27 Pejabat Bengkulu, Bengkuluexpress, 17 May 2018, retrieved from https://bengkuluekspress.com/kpk-sudahpenjarakan-27-pejabat-bengkulu/.

[31] Mediaindonesia.com, Menguak Korupsi Legislasi, 4 April 2016, retrieved from https://mediaindonesia.com/editorials/detail_editoria ls/706-menguak-korupsi-legislasi.

[32] Kurnia D., Ramadhan B., Jaksa Ungkap Kronologi Pemberian Suap Reklamasi kepada Sanusi, Republika, 24 August 2016, retrieved from https://republika.co.id/berita/nasional/hukum/16/08/ 24/oceqb9330-jaksa-ungkap-kronologi-pemberiansuap-reklamasi-kepada-sanusi.

[33] Saputra A., MA Sunat Hukuman Koruptor Izin Reklamasi Eks DPRD DKI M Sanusi, Detik, 1 November 2019, retrieved from https://news.detik.com/berita/d-4768703/ma-sunathukuman-koruptor-izin-reklamasi-eks-dprd-dki-msanusi.

[34] Friastuti R., Eks Presdir Podomoro Land Ariesman Wijaya Divonis 3 Tahun Bui, Detik, 1 September 2016, retrieved from https://news.detik.com/berita/d-3288737/ekspresdir-podomoro-land-ariesman-wijaya-divonis-3tahun-bui.
[35] Arief B., Korupsi dan Upaya Penegakan Hukum, Jakarta: Adika Remaja Indonesia, 2006.

[36] Muladi, Kapita selekta sistem peradilan pidana, Semarang: Badan Penerbit Universitas Diponegoro, 1995.

[37] Purawan A. A., Korupsi Legislasi Dalam Pembentukan Peraturan Perundang-Undangan, Jurnal Rechts Vinding: Media Pembinaan Hukum Nasional, vol. 3, no. 3, pp. 347-363, 2014.

[38] World Bank, Anticorruption in Trasition to the Policy Debate, Washington D.C: World Bank, 2000.

[39] Klitgaard R. E., Abaroa R. M., Parris H. L., Corrupt cities: a practical guide to cure and prevention, Washington D.C: World Bank, 2000.

[40] Ekatjahjana W., Pembentukan peraturan perundang-undangan: dasar-dasar dan teknik penyusunannya, Bandung: Citra Aditya Bakti, 2008.

[41] Panjaitan S. P., Jaminan Perlindungan Konstitusional Hak Tiap Orang Untuk Memperoleh Informasi dan Berkomunikasi, Jurnal Simbur Cahaya, vol. 15, no. 42, pp. 1957-1958, 2010.

[42] Huntington S. P., Nelson J., Partisipasi politik di negara berkembang [Indonesian], Jakarta: Rineka Cipta, 1994.

[43] Wahanisa, R., Niravita, A., Mahfud, M.A., Aminah, S. (2021). Public participation by optimizing rural spatial planning to prevent functional conversion of agricultural land to non-agricultural use. Universal Journal of Agricultural Research, 9(5), pp. 149-155

[44] Wahanisa, R., Hidayat, A., Benny Riyanto, R., Anggono, B.D. (2021). Problems of disputes/conflicts over land acquisition towards development for public interest in Indonesia. International Journal of Criminology and Sociology, 10, 320-325.

\section{Contribution of Individual Authors to the Creation of a Scientific Article (Ghostwriting Policy)}

Bayu Dwi Anggono: conceptualization, formal analysis, methodology, writing - original draft and writing - review \& editing.

Rofi Wahanisa: data curation, formal analysis, validation and writing - review \& editing.

\section{Sources of Funding for Research Presented in a Scientific Article or Scientific Article Itself}

The authors declare there is no potential conflict of interest.

\section{Creative Commons Attribution License 4.0 (Attribution 4.0 International, CC BY 4.0)}

This article is published under the terms of the Creative Commons Attribution License 4.0

https://creativecommons.org/licenses/by/4.0/deed.en $\underline{\mathrm{US}}$ 